Article

\title{
Densification and Fuel Properties of Onion Husks
}

\author{
Sławomir Obidziński ${ }^{1, *}{ }^{\mathbb{D}}$, Magdalena Dołżyńska ${ }^{1}$ [, Małgorzata Kowczyk-Sadowy ${ }^{1}$, \\ Krzysztof Jadwisieńczak ${ }^{2}$ and Paweł Sobczak ${ }^{3}$ D \\ 1 Faculty of Civil and Environmental Sciences, Białystok University of Technology, Wiejska 45E Street, 15-531 \\ Białystok, Poland; m.dolzynska@pb.edu.pl (M.D.); m.kowczyk@pb.edu.pl (M.K.-S.) \\ 2 Faculty of Technical Sciences, University of Warmia and Mazury in Olsztyn, Oczapowskiego 11 Street, \\ 10-719 Olsztyn, Poland; krzychj@moskit.uwm.edu.pl \\ 3 Faculty of Production Engineering, University of Life Sciences in Lublin, Głęboka28 Street, 20-612 Lublin, \\ Poland; pawel.sobczak@up.lublin.pl \\ * Correspondence: s.obidzinski@pb.edu.pl
}

Received: 31 October 2019; Accepted: 30 November 2019; Published: 9 December 2019

\begin{abstract}
The aim of the described research was to assess the suitability of onion husk waste as a material for the production of solid fuels in the form of granules (pellets). Due to the low susceptibility to thickening of onion husks, the addition of a binder in the form of potato pulp was used (waste with a high starch content). Both wastes were subjected to elemental analysis determining the content of $C$, $\mathrm{H}, \mathrm{N}, \mathrm{S}, \mathrm{Cl}$, and their HHV (High Heating Value) and LHV (Low Heating Value). Mixtures containing the addition of $10 \%, 15 \%$, and $20 \%$ potato pulp to onion husks were subjected to granulation in a "flat matrix-thickening rollers" operating system at three rotational speeds of the granulator matrix a 170, 220, and $270 \mathrm{rpm}$. The influence of the potato pulp addition and matrix rotational speed on the quality of the obtained pellet was determined. The highest quality product was combusted in a low-power boiler with a retort grate, and the content of $\mathrm{CO}, \mathrm{CO}_{2}, \mathrm{SO}_{2}, \mathrm{NO}$, and $\mathrm{HCl}$ in the exhaust gas was determined. The highest quality granulate was obtained from a mixture containing $10 \%$ potato pulp, which was compacted at $170 \mathrm{rpm}$ matrix, where the kinetic strength was $99.50 \%$ and the density was about $650 \mathrm{k} \cdot \mathrm{gm}^{-3}$. The results of the combustion emissions from onion husk granules exceed the requirements of the EcoDesign Directive with the greatest being the case of CO.
\end{abstract}

Keywords: onion husks; potato pulp; densification; combustion; emission

\section{Introduction}

In recent years, biomass, including waste biomass (bio-waste) from the agri-food industry, has increasingly been used as a raw material for heat and electricity production due to the commonly observed requirement to reduce carbon dioxide emissions [1].

Bio-waste is food and kitchen waste from caterers, households, commercial premises, and food processing plants [2]. Every month, millions of tons of these kinds of bio-waste are produced. Some are allocated to landfills, and some are exported to third world countries. This has a serious impact on the environment, human health, and wildlife. For this reason, many new processes for the generation of energy from waste are constantly being developed [3-8].

One of the raw waste materials generated in vegetable processing plants is post-production onion waste. According to the Polish Act on waste of 27 April 2001 [9], onion husk was in group 02 (waste from agriculture, horticulture, hydroponics, fishing, forestry, hunting, and food processing), with code 020380 (pomace, sediments, and other wastes from the processing of plant products).

According to Benitez et al. [10], waste from onion processing is mainly onion husks (skins), i.e., two outer fleshy scales (skins) and roots removed from the vegetable during industrial peeling as well damaged or undersized malformed bulbs. Waldron [11] considered these wastes as an environmental 
problem. Onion waste, because of its characteristic aroma, is unsuitable in high concentrations for fodder nor as an inorganic fertilizer because of the rapid development of phytogenetic agents.

Ly and co-workers [12] reported that the dry outer skins of onion contain high contents of quercetin, quercetin glycoside, and their oxidative products, which may be effective antioxidants against non-enzymatic lipid oxidation. Many studies have confirmed that different parts of the onion bulb may serve as promising sources of natural antioxidants [13,14]. On the other hand, Benitez and co-workers [10] found that onion composition is variable and depends on the bulb section cultivar, environment, maturation stage, and storage time. Therefore, it is necessary to study the composition of each part to know its potential purposes.

Solid waste of agri-food origins can be submitted to a densification (agglomeration) process, where the material obtains a permanent geometric form of a granulate (agglomerate, pellet) or briquette due to external and internal forces [15]. The granulation process (agglomeration, densification) of waste materials favors their transport and storage (increase of bulk density) and allows their application in installations with automatic fuel feeding systems. Moreover, through the process of densification, it is possible to obtain a product that is a mix of a few components, which allows modeling of the required properties of the produced fuel [16].

Ohman and colleagues [17] stated that the quality of biomass pellets can be improved by the addition of a hydrolytic post-production waste, resulting from the production of ethanol from lignocellulose. As a result of the addition, the heating value of pellets increased, and the ash content decreased. Miranda and colleagues [18], who compacted olive waste pulp (a by-product of olive oil production), found that the addition of Pyrenean oak waste to the olive pulp ensured a more effective compacting of the mixture, improved the kinetic durability of the obtained granulate, and reduced its ash content. Chou et al. [19,20], in searching for the optimal conditions for obtaining fuel briquettes from rice waste (straw and bran), found that along with the increase of rice bran in the compacted mixture, the strength of the briquette and its calorific value increased in the process of densification in a piston-matrix system.

Celma and colleagues [21] investigated the granulate from industrial post-production tomato waste (skins and seed cores), concluding that its hardness and kinetic durability depends on the moisture of the used biomass, as well as on further activities related to the reduction of its humidity after compaction and the storage time of the obtained granulate. Stahl and Berghel [22] determined that with the increase in the turnip waste content in the compacted mixture with sawdust, the mechanical strength and density of the obtained granulate, as well as the energy consumption of the agglomeration process, were decreased. Sotannde and colleagues [23], in examining the effect of binder addition (arabic gum and cassava starch) in the process of charred (torrified) wood waste briquetting, stated that the use of both binder materials allowed high-quality briquettes (high kinetic durability and calorific value) to be obtained.

One of the post-production wastes generated from agri-food processing plants is buckwheat husk. According to Chachułowa and colleagues [24], buckwheat husk can be used as an additive to animal feed, which may be stored longer. However, according to Chachułowa and co-workers [24], the low bulk density of the husk impedes its transport, so processing at the plants in which it is produced is required. The tests conducted by the authors of this paper allowed for the conclusion that raw buckwheat husk is a material with low susceptibility to densification. Based on the tests, it was found that buckwheat husk has a low moisture content of approximately $8.4 \%$ and low bulk density of about $186 \mathrm{~kg} \cdot \mathrm{m}^{-3}$. Pressure agglomeration of husks with such low humidity gives unsatisfactory results. In order to increase its susceptibility to compaction and to obtain high-density granules, some pretreatments should be done, for example, increased humidity or a binder additive. Potato pulp can be such an addition, as demonstrated by earlier authors' research [25-27].

Undertaking research related to post-harvest waste management allows public awareness of the use of agricultural waste as energy sources to be raised, and also shows a specific example of how to 
convert waste biomass into fuel. The use of onion husk residue for fuel purposes is not a topic that is often discussed by researchers dealing with this waste.

According to earlier research of compacting post-production onion waste carried out by the authors [28], onion waste is a material characterized by a small susceptibility to densification. During pelleting, a high process temperature is required in order to obtain pellets with satisfactory quality parameters. An increased moisture content in the densified onion waste has a significant impact on the pelleting process and the quality of the obtained pellets. The authors [28] found that increasing the moisture content of the densified onion waste from $17.1 \%$ to $24 \%$ resulted in a decreased energy consumption of the pelleting device by approximately $22.6 \%$ (from 2.61 to $2.02 \mathrm{~kW}$ ) and a simultaneous reduction in the pellets' density by approximately $14.8 \%$ (from 1280.48 to $1090.29 \mathrm{~kg} \cdot \mathrm{m}^{-3}$ ) and a slight reduction in the kinetic durability of pellets by approximately $0.5 \%$ (from $97.80 \%$ to $97.24 \%$ ).

A continuation of the above tests is presented in this work, where the impact of a binder addition in the form of potato pulp on the compaction process of onion husks was determined. The mechanical and fuel properties of the obtained granulate, as well as studies of the effects of its combustion, were tested to provide answers on its usefulness for energy purposes.

The purpose of the work was to analyze (based on research results) the fuel suitability of onion waste. The aim of the work was to determine the impact of material and process parameters on the energy consumption of the granulation process and on the quality of the obtained granulate (density and kinetic durability), its elementary analysis, heat of combustion, and calorific value as well as to determine the effects of combustion of the obtained granulate.

\section{Materials and Methods}

\subsection{Materials}

The paper presents the results of research on the granulation process of ground onion waste (Figure 1) obtained from the peeling onion plant located in Melno for the needs of the P.P.H.U (Production, Service and Trade Enterprise) cold store Eldom Grudziadz.

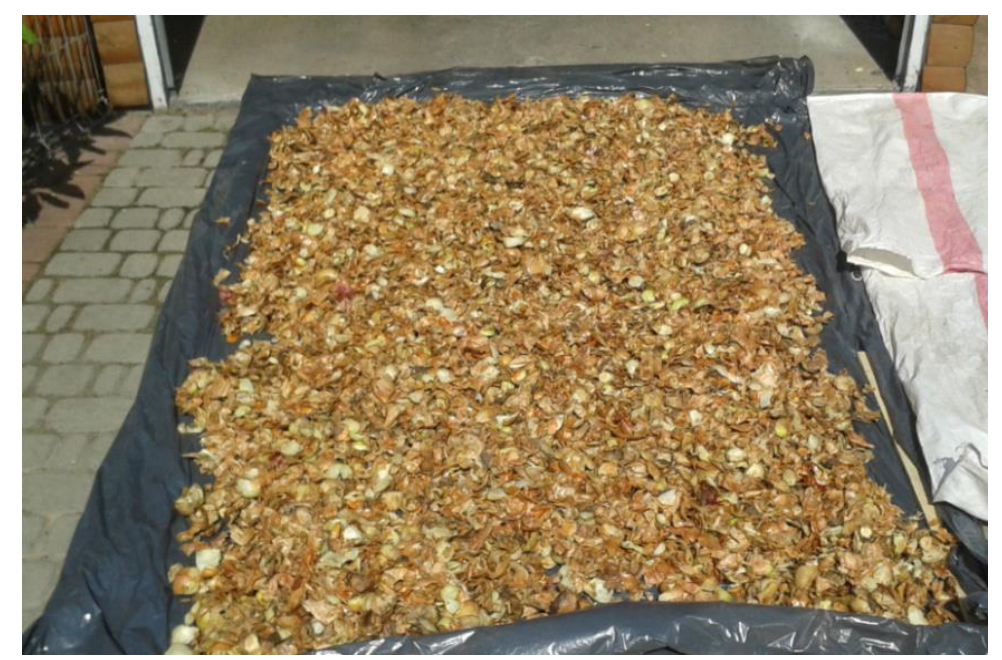

(a)

Figure 1. Cont. 


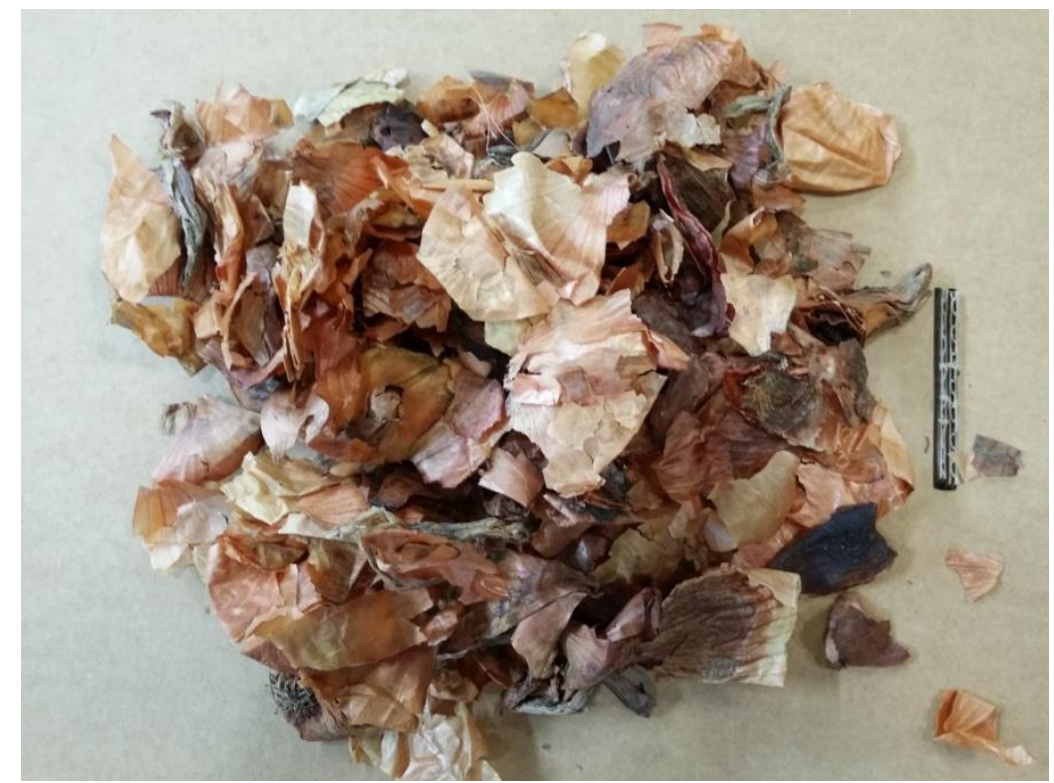

(b)

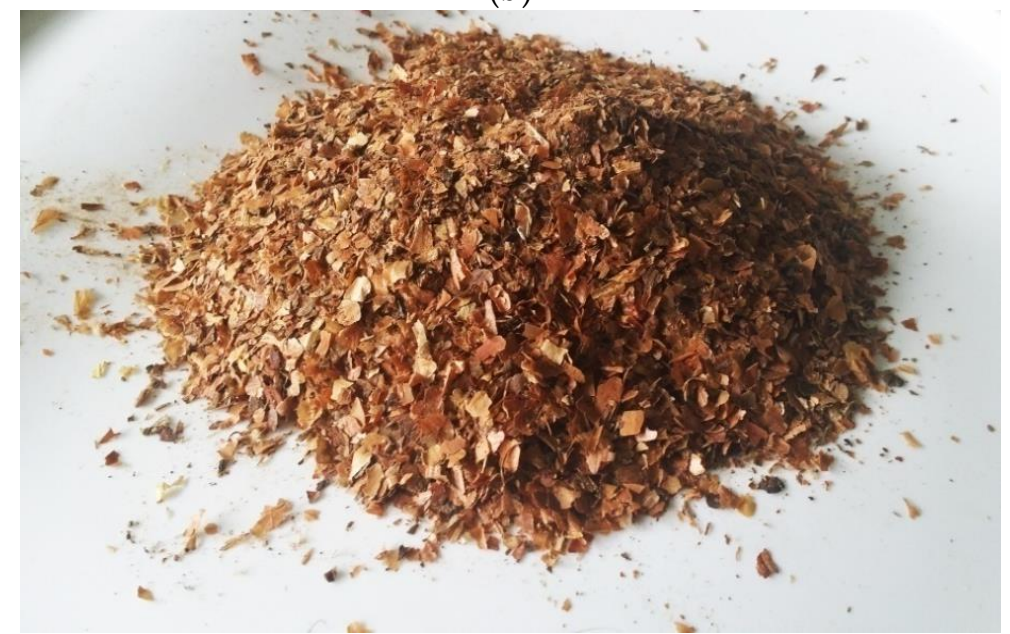

(c)

Figure 1. Post-production onion waste: (a) during drying in ambient conditions, (b) after drying, (c) in crushed and dried form own photograph.

Pre-drying of the obtained post-production waste was carried out in atmospheric conditions by means of free convection. The collected raw material was loosely distributed in field conditions (Figure 1a). Pre-dried onion waste (Figure 1b) was ground to a particle size of approximately $5 \mathrm{~mm}$ and smaller (Figure 1c) using a "Bak" H-111 flail shredder equipped with $5 \mathrm{~mm}$ sieves.

\subsection{Methods}

\subsubsection{Physicochemical Properties of the Raw Materials}

Determination of the granulometric distribution of shredded onion husk waste was carried out in accordance with $[29,30]$, using a LPz-2e laboratory shaker from Multiserv Morek company, equipped with a set of sieves with a mesh diameter of $6,5,4,3.15,2,1.6,1,0.5,0.25,0.125$, and $0.063 \mathrm{~mm}$. Each time, a sample of $100 \mathrm{~g}$ of the raw material was dosed into the upper sieve and the shaker was activated for $5 \mathrm{~min}$. After this time, the residue that was on each of the sieves was weighed on an analytical balance. The analysis was repeated three times. The result was an arithmetic average of the tests. 
Before the pressure agglomeration process, the material's (onion husk) moisture content was tested in accordance with [31], using a WPE 300S moisture analyzer with an accuracy of $0.01 \%$. The moisture content of five samples weighing approximately $5 \mathrm{~g}$ each was determined. The average of the obtained results was taken as the final result of the moisture determination. The bulk density of tested materials was analyzed in accordance with [32].

The content of $\mathrm{C}, \mathrm{H}, \mathrm{N}$, and $\mathrm{S}$ were determined using the LECO CHN628 elementary analyzer in accordance with $[16,33,34]$. The chlorine content in the onion husks and potato pulp was determined using the S2 PICOFOX fluorescence spectrometer under the method given by the manufacturer. Analysis of the volatile parts content (according to [35,36]), moisture content (according to [36]), and ash content (according to [37]) in the onion husks and potato pulp was carried out on the LECO TGA-701 analyzer. The heat of combustion (HHV) was tested in accordance with [38] using the $\mathrm{Kl}-12 \mathrm{Mn}$ calorimeter. The calculations of the low heating value (LHV) were based on the material moisture and hydrogen content.

\subsubsection{Pressure Agglomeration Process}

Tests of the pressure agglomeration process (granulation) were carried out at the SS-4 laboratory stand (Figure 2), in which the main element is a P-300 granulator with a flat matrix, as described in previous works $[16,27]$.

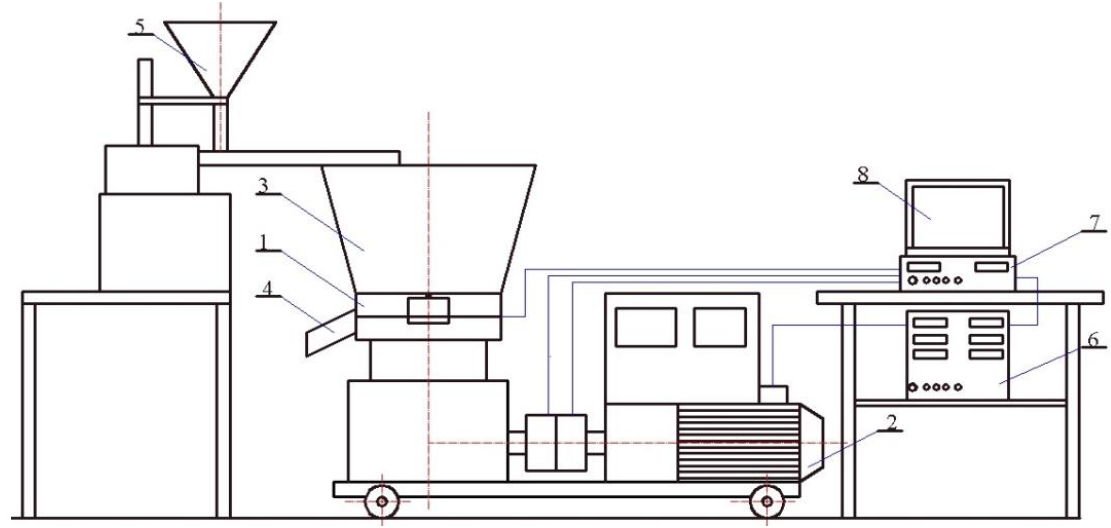

(a)

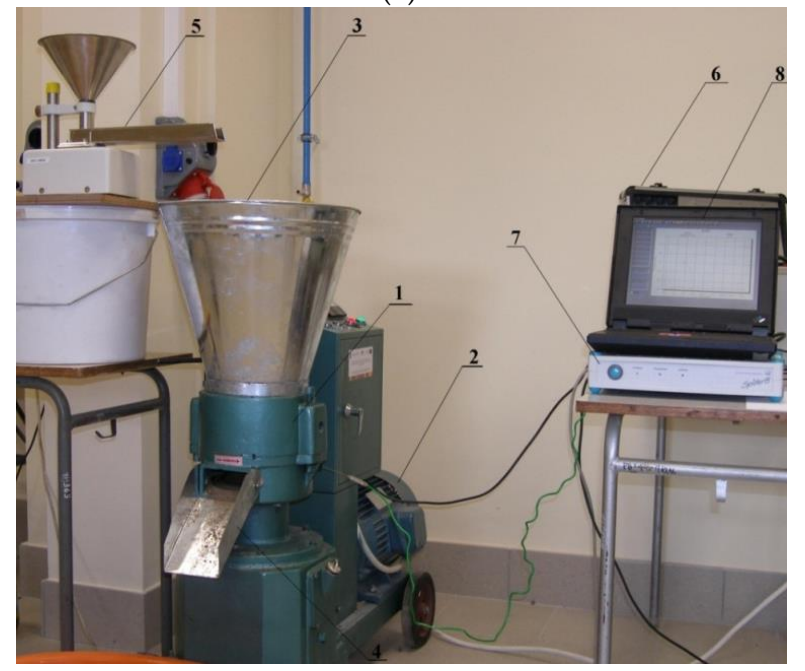

(b)

Figure 2. View of the laboratory stand SS-4: (a) scheme: 1-working system of the granulator, 2-electric motor (Y132M, 7.5 kW, $1440 \mathrm{obr} \cdot \mathrm{min}^{-1}$ ), 3-raw material feed, 4-spill granulate, 5-vibrating dispenser (FRITISCH LABORET 24), 6-power demand universal meter (METROL KWS 1083, max 20 kW, 7-Spider 8 recorder, 8 - computer, (b) view of SS-4. 
Densification tests of the onion husks and potato pulp mixture were carried out with the following input parameters:

$\mathrm{x}_{1}=\mathrm{z}_{\mathrm{W}}$-potato pulp content $(10 \%, 15 \%$ and $20 \%)$ and

$\mathrm{x}_{2}=\mathrm{n}_{\mathrm{m}}$-granulator matrix rotational speed (170, 220 and $\left.279 \mathrm{rpm}\right)$.

The granulators matrix holes were $6 \mathrm{~mm}$ in diameter and $28 \mathrm{~mm}$ in length. The mass flow rate of the raw material mixtures through the granulator working system was set for all tests at the level of approximately $50 \mathrm{~kg} \cdot \mathrm{h}^{-1}$.

The kinetic durability of the obtained pellets was tested according to [39] by the Holmen method. The density of pellets was determined as the ratio of the mass and volume of 10 randomly selected granules.

\subsubsection{Combustion of Pellets}

Combustion in a low power boiler $(25 \mathrm{~kW})$ with a rotary grate (Figure 3) was carried out in order to verify the emissions of the produced pellets. The laboratory stand was described in previous papers [40,41].

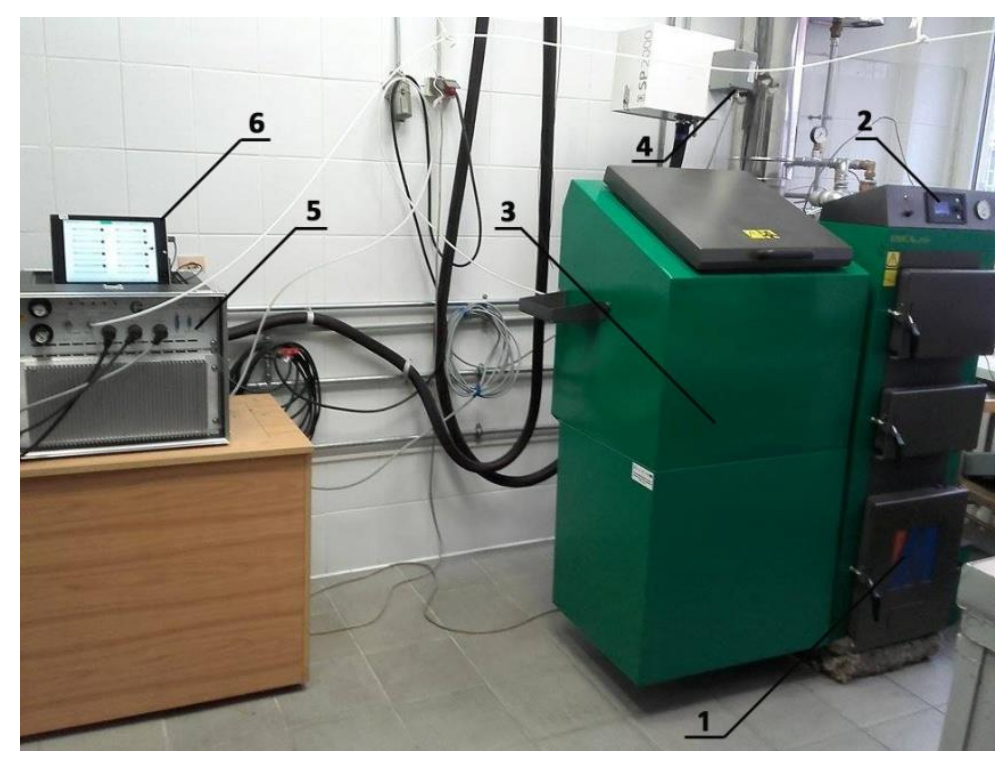

Figure 3. Low Emission Combustion Technologies laboratory stand: 1-Moderator Unica VentoEko 25 kW boiler, 2-controller of the boiler, 3-fuel tank, 4-exhaust sampling place, 5-MCA10 analyzer, 6-Microsoft tablet for archiving obtained measurement results.

The laboratory station includes a Moderator (Hajnówka) Unica VentoEko boiler and Dr. Födisch MCA10 flue gas analyzer.

In the combustion tests, pellet samples of approximately $10 \mathrm{~kg}$ were dosed into the boiler by an automatically controlled screw feeder. The pellet mass flow and the airflow were set by a controller in the so-called automatic Fuzzy Logic mode. The combusted fuel mass flow was constant at $3.2 \mathrm{~kg} \cdot \mathrm{h}^{-1}$. After obtaining stable combustion conditions, the boiler controller may change the mass and air flow to a small extent, which was negligible for the planned experiment.

The contents of $\mathrm{CO}_{2}, \mathrm{CO}, \mathrm{NO}$, and $\mathrm{SO}_{2}$ in the flue gases were normalized to the $10 \%$ content of oxygen $\mathrm{O}_{2}$ in accordance to the formula [37]:

$$
Z_{s 2}=\frac{21-O_{2}^{\prime}}{\left(21-O_{2}^{\prime \prime}\right)} \cdot Z_{s 1}\left[\%, \mathrm{mg} \cdot \mathrm{m}^{-3}\right]
$$

where: 
$Z_{s 1}$-the actual compound content in the exhaust gas $\left[\%, \mathrm{mg} \cdot \mathrm{Nm}^{-3}\right]$;

$Z_{s 2}$-content of the compound in the exhaust gas for the calculated concentration of oxygen [\%, $\left.\mathrm{mg} \cdot \mathrm{Nm}^{-3}\right]$;

$\mathrm{O}_{2}^{\prime}$-set oxygen content in the exhaust [\%]; and

$\mathrm{O}_{2}^{\prime \prime}$-actual (obtained) oxygen content in the exhaust gas [\%].

The excess air factor, $\lambda$, was computed based on the formula used for technical calculations:

$$
\lambda=\frac{21.5}{21.5-O_{2}^{\prime \prime}} \quad[-] .
$$

\section{Results and Discussion}

\subsection{Physicochemical Properties of Raw Materials}

Table 1 presents the elemental composition, moisture content, volatile matter content, and ash content in onion husks and potato pulp.

Table 1. Onion husks and potato pulp.

\begin{tabular}{|c|c|c|}
\hline Property & Onion Husks & Potato Pulp \\
\hline Moisture [\%] $w b$ & $9.45 \pm 0.26$ & $90.11 \pm 0.12$ \\
\hline Bulk density $\left[\mathrm{kg} \cdot \mathrm{m}^{-3}\right] w b$ & $159.40 \pm 7.34$ & $521.24 \pm 1.87$ \\
\hline Volative matter $[\%] d b$ & $62.11 \pm 0.42$ & $68.44 \pm 0.55$ \\
\hline $\operatorname{Ash}[\%] d b$ & $19.80 \pm 0.38$ & $12.19 \pm 0.24$ \\
\hline Carbon [\%] $d b$ & $30.60 \pm 0.46$ & $41.27 \pm 0.56$ \\
\hline Hydrogen $[\%] d b$ & $3.85 \pm 0.01$ & $5.36 \pm 0.02$ \\
\hline Nitrogen [\%] $d b$ & $1.00 \pm 0.00$ & $0.88 \pm 0.00$ \\
\hline Sulphur [\%] $d b$ & $0.499 \pm 0.001$ & $0.441 \pm 0.002$ \\
\hline Chlorine $[\%] d b$ & 0.025 & 0.013 \\
\hline Oxygen ${ }^{1}[\%] d b$ & 64.03 & 47.96 \\
\hline $\mathrm{HHV}\left[\mathrm{MJ} \cdot \mathrm{kg}^{-1}\right] w b$ & $12.077 \pm 0.10$ & $2.503 \pm 0.059^{2}$ \\
\hline $\mathrm{LHV}\left[\mathrm{MJ} \cdot \mathrm{kg}^{-1}\right] w b$ & 10.491 & 0.242 \\
\hline
\end{tabular}

${ }^{1}$ By difference, ${ }^{2}$ calculated by the method described in [25].

Biomass, when compared to hard coal, shows much greater variability of physical and energy parameters [42]. Compared to hard coal, solid biomass contains less elemental carbon; more oxygen, silicon, and potassium; less aluminum and iron; and has a lower calorific value and lower density [43].

In addition to the chemical composition of biomass, which has a direct impact on the effects of its combustion [40,44], the moisture and ash content are the decisive properties for the use of biomass [45]. The high moisture contents of fuel have adverse effects on the combustion process, causing a decrease in the combustion temperature and making the combustion of fuels more difficult. The effect of this is an increase in the boiler outlet loss and a decrease in its efficiency [46]. The use of raw potato pulp as an independent fuel in combustion processes is significantly hampered by its high moisture content. Thus, it is a material that may be used in the form of a small additive in combustion installations.

Carbon, hydrogen, and oxygen are the main components of solid biofuels. During combustion, carbon and hydrogen, through exothermic reactions, are oxidized to carbon dioxide $\mathrm{CO}_{2}$ and water vapor $\mathrm{H}_{2} \mathrm{O}$, so their content has a positive effect on the heat of combustion of biofuels. The content of oxygen is a ballast in the combustion processes [47]. There are large differences between the carbon content of different types of biomass. According to Saidur et al. [48], wood-based materials are richer in carbon than herbaceous biomass (stems, leaves, straw, scales), hence they are characterized by higher values of heat of combustion.

The authors used a simplification by calculating the oxygen content as a difference from the content of other elements in the tested materials. However, it should be noted that in the case of onions, 
due to their specific layered structure, the presence of silicon compounds, resulting from inaccurate waste treatment, is also possible. These inclusions can also cause a high ash content in onion skins (so-called secondary ash).

An increase in the potato pulp content from $10 \%$ to $20 \%$ in the mixture with onion husks caused a decrease in the LHV by approximately $10.7 \%$ (Figure 4). Kriżan et al. [49] produced briquettes and pellets of various diameters from maize straw and woody biomass. Their experiment showed that a calorific value of 6-mm diameter pellets ranged from 16.99 to $17.80 \mathrm{MJ} \cdot \mathrm{kg}^{-1}$. The calorific value of 8-mm diameter pellets ranged from 16.63 to $17.20 \mathrm{MJ} \cdot \mathrm{kg}^{-1}$. Nevertheless, the corresponding calorific value of briquettes ranged from 14.99 to $15.66 \mathrm{MJ} \cdot \mathrm{kg}^{-1}$. Additionally, the analysis showed that the ash content was also affected by the pellet diameter. The ash content of 6-mm diameter pellets was observed as $4.9 \%$ of the total volume while 8 - $\mathrm{mm}$ diameter pellets was $5.5 \%$.

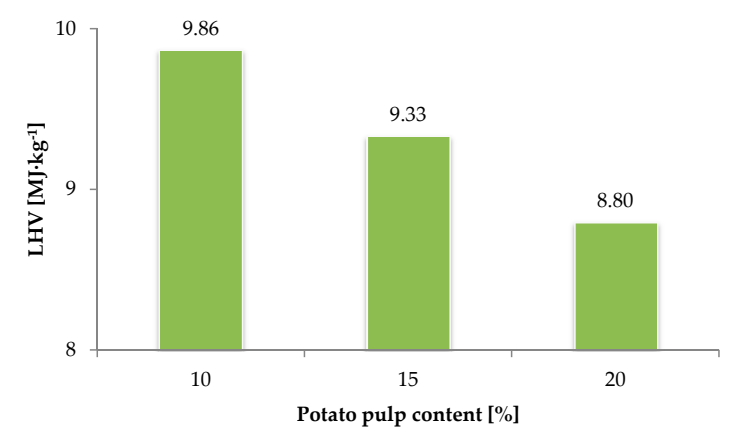

Figure 4. LHV of cherry stones granules on the content of rye bran.

The decrease in the LHV (Figure 4) is due to onion husks having a higher calorific value than potato pulp. Zajac and Szyszlak-Bargłowicz [48], using the addition of rye bran for safflower mallow, also noticed a decrease in the calorific value of the irobtained pellets. According to Obidziński and colleagues [50], the use of a binder in the form of potato pulp in a mixture with buckwheat husk also caused a decrease in the calorific value of the granulate.

A one-factor analysis of variance (one-dimensional Kolmogorov-Smirnov significance test) at the significance level of $\alpha=0.05$ indicated significant differences between the calorific value of the granulate obtained with the increasing content of potato pulp in a mixture with onion husk.

Figure 5 presents the particle size distribution of onion husks before the pressure agglomeration process.

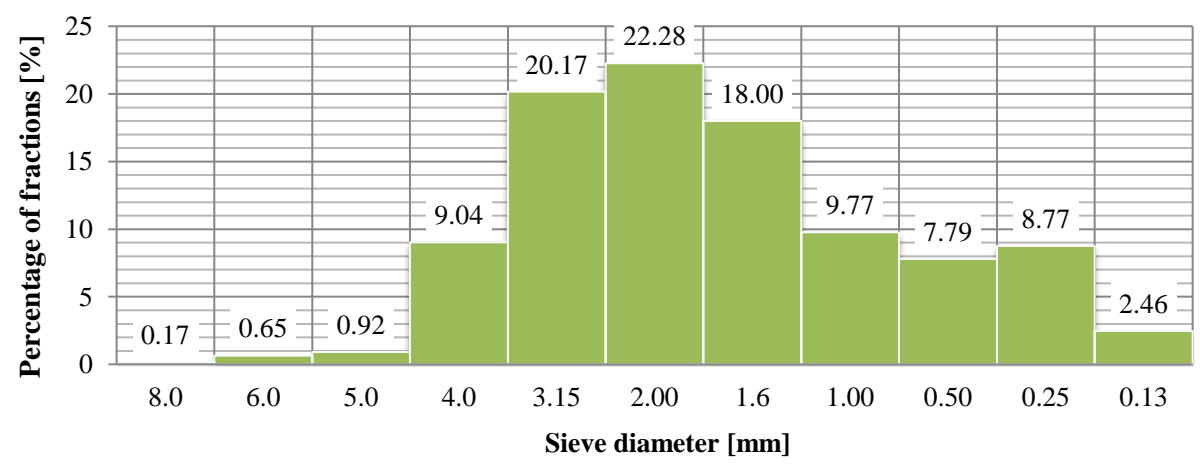

Figure 5. Onion grain size composition.

According to Zawiślak et al. [51], materials with a particle size from 0.4 to $2 \mathrm{~mm}$ are most suitable for granulation. Research carried out by Castellano et al. [52] showed a reduction in the energy consumption of pelleting along with a reduction of the particle size of wood and non-wood materials from 4 to $2 \mathrm{~mm}$. 


\subsection{Pressure Agglomeration Process}

The influence of process and material factors (rotational speed of the matrix and potato pulp content) on the kinetic durability of the obtained granules is shown in Figure 6.

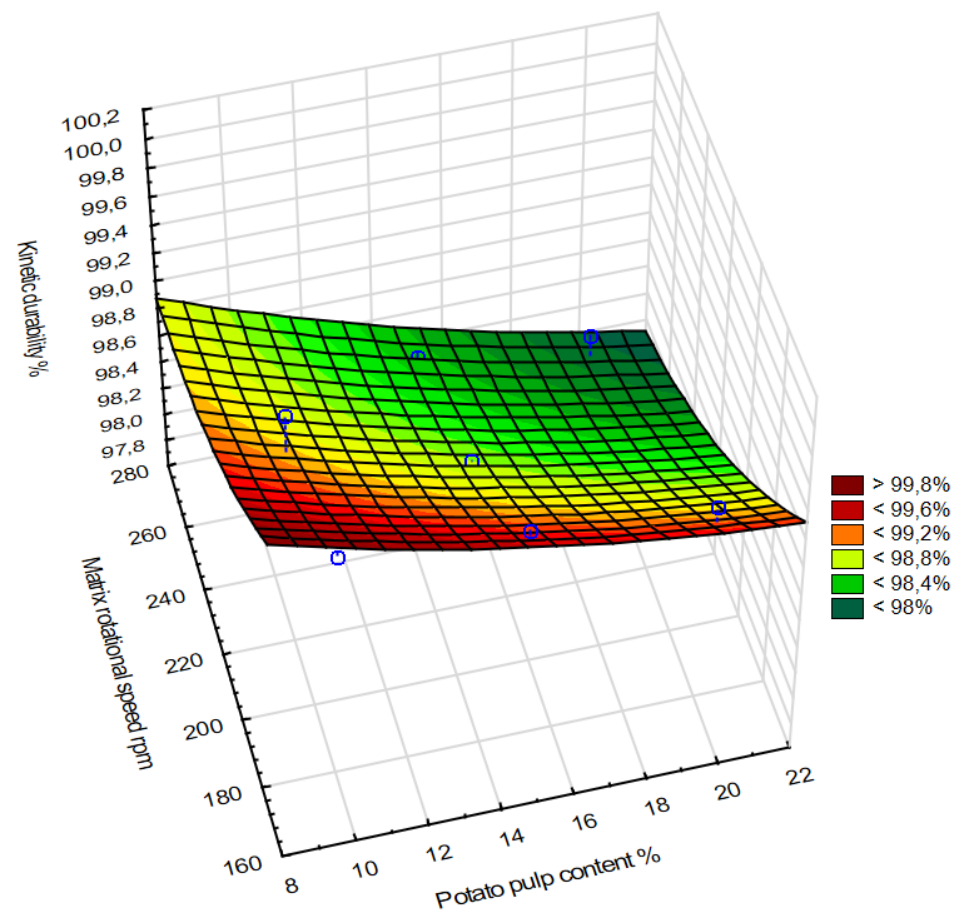

Figure 6. Impact of the potato pulp and rotational speed of the matrix on the kinetic durability of onion husk granules.

After analyzing Figure 6, it was found that an increase in the potato pulp content from $10 \%$ to $20 \%$ in the onion husk mixture resulted in a slight decrease in the kinetic durability of the obtained granulate at each of the tested rotational speeds of the granulator matrix. For example, increasing the content of the potato pulp from $10 \%$ to $20 \%$ in the mixture with onion husks at a matrix rotational speed of $170 \mathrm{rpm}$ caused a decrease in the kinetic durability of the obtained granulate from $99.5 \%$ to $99.3 \%$.

It should be noted that the addition of potato pulp to the onion husks allowed high-quality granules to be obtained, i.e., high kinetic durability $(99.5 \%-98.2 \%)$. In addition, these are higher values than those obtained for onion husk granules without the use of a binder [28]. This is caused by the action of potato starch, which, in combination with moisture and high temperatures, forms a sticky gel during granulation [50]. After cooling, the gel leads to the formation of strong bonds between the particles of the mixture. As reported by Kaliyan and Morey [53], under the influence of thickening pressure, natural biomass binders may soften in the presence of moisture (e.g., water-soluble carbohydrates) or in some cases at elevated temperature (e.g., lignin, protein, starch, and fat).

After removing the pressure and cooling, the binder cures to form bridges (bonds) between the particles. As a result, the particles join together, increasing the durability of the resulting product. In addition, the activation (softening) of natural ingredients bound by moisture and temperature in the glass transition is necessary for the production of very durable briquettes and granules.

The tests (Figure 6) allowed the statement that an increase in the rotational speed of the matrix from 170 to $270 \mathrm{rpm}$ caused a slight decrease in the kinetic strength of the granulate obtained from a mixture of onion husk and potato pulp (by approximately 1\%), at each of the tested levels of potato pulp. For example, increasing the rotational speed of the matrix from 170 to $270 \mathrm{rpm}$ with a $10 \%$ addition of potato pulp in the mixture caused a decrease in the kinetic durability of the obtained granulate from $99.5 \%$ to $98.6 \%$. 
The high degree of comminution of agglomerated particles had a favorable effect on the value of kinetic durability in the case of onion skins (Figure 6). This is confirmed by Kaliyan and Morey [54], who listed the moisture content and particle size of the compacted material as one of the most important factors that affects the magnitude of forces during the compaction process. Alakangas and Paju [55], Obidziński [56], and Hejft [57] claim that the rotational speed of the matrix influences the value of thickening pressures, while lowering the rotational speed results in higher thickening pressures, and thus granules with higher kinetic durability are obtained.

The multiple regression coefficient for the tested model (equation) was $R^{2}=93.95 \%$, which means a good fit of the model describing the kinetic strength of the onion husk granulate depending on the addition of potato pulp and the rotational speed of the granulator matrix.

The influence of process and materials factors (rotational speed of the matrix and potato pulp content) on the density of obtained granules is shown in Figure 7.

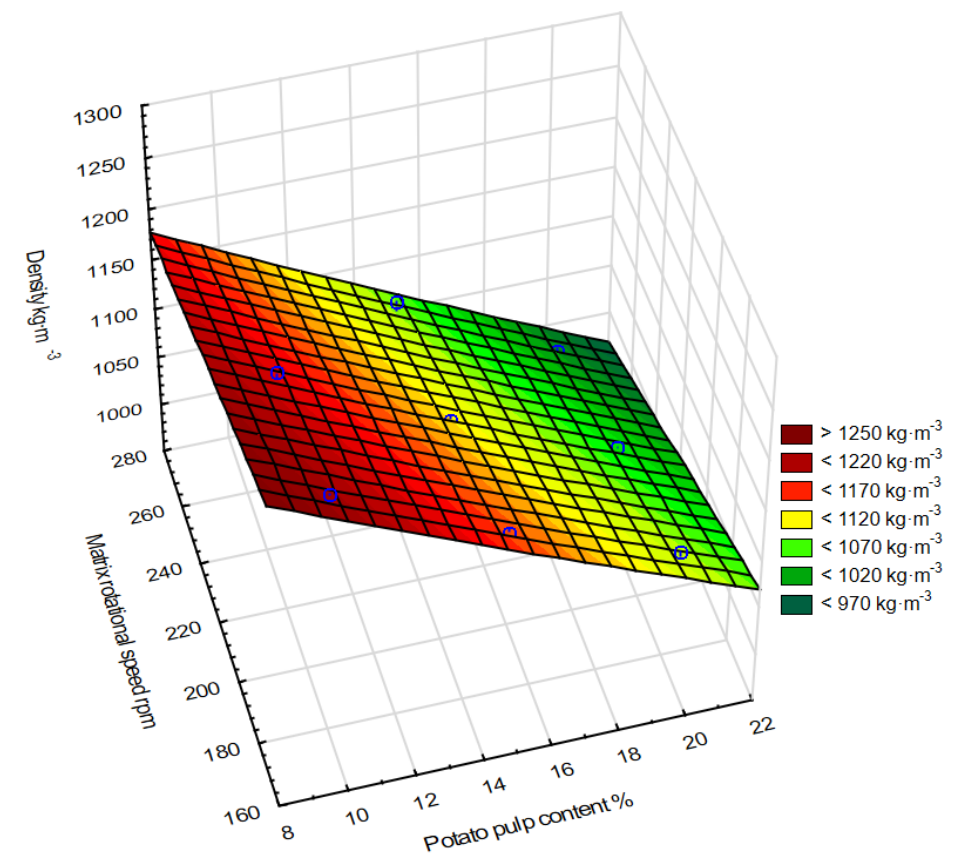

Figure 7. Impact of the potato pulp and rotational speed of the matrix on the density of onion husk granules.

From Figure 7, it was found that an increase in the potato pulp content from $10 \%$ to $20 \%$ in the mixture with onion husk resulted in a decrease in the physical density of the obtained granulate from 1225.62 to $1001.36 \mathrm{~kg} \cdot \mathrm{m}^{-3}$, at all tested rotational granulator matrix speeds. The highest physical density $\left(1225.62 \mathrm{~kg} \cdot \mathrm{m}^{-3}\right)$ was obtained for pellets obtained from onion skins with $10 \%$ potato pulp, at a matrix speed of $170 \mathrm{rpm}$. With an increase in the amount of additive from $10 \%$ to $20 \%$, a decrease in granulate density was observed. For example, at $170 \mathrm{rpm}$, this decrease was about $11 \%$.

On the basis of the descriptive statistics (Figure 7), it was found that mixtures with the rotational speed of $170 \mathrm{rpm}$ were characterized by the greatest variation in physical density while the lowest values were obtained at $270 \mathrm{rpm}$.

The physical density values of onion granules obtained during the tests with the addition of potato pulp were similar to the physical density of granules obtained from agglomerated onion skins without its addition [28].

It should be noted that as the amount of potato pulp added increases, the moisture content of the agglomerated mixture also increases. Moisture content, which acts as a lubricant and binder in the agglomeration process [58], is considered the most important factor affecting the quality of granules $[56,57,59]$. Mani and colleagues [60] claim that pellets made from maize with lower moisture 
contents $(5 \%-10 \%)$ have a higher density than those with moisture contents above $15 \%$. This is confirmed by Shaw and Tabil [61], who, like many other researchers, stated that the lower humidity of the compacted material increases the density of the obtained granulate. Obidziński [27], by thickening buckwheat hulls with $15 \%, 20 \%$, and $25 \%$ potato pulp addition, stated that the decrease in granulate density along with the increase in the pulp is caused by a decrease in the friction coefficient of the material against the walls of the holes in the granulator's matrix.

The bulk density of the obtained pellets ranged from $580 \mathrm{~kg} \cdot \mathrm{m}^{-3}$ for pellets produced with the addition of $20 \%$ of potato pulp to $640 \mathrm{~kg} \cdot \mathrm{m}^{-3}$ for the $10 \%$ addition.

The multiple regression coefficient for the tested model (equation) was $\mathrm{R}^{2}=99.62 \%$, which means a good fit of the model describing the physical density of onion husk granules depending on the addition of potato pulp and rotational speed of the granulator matrix.

The influence of the process and materials factors (rotational speed of the matrix and potato pulp content) on the demand for granulator power of the obtained granules is shown in Figure 8.

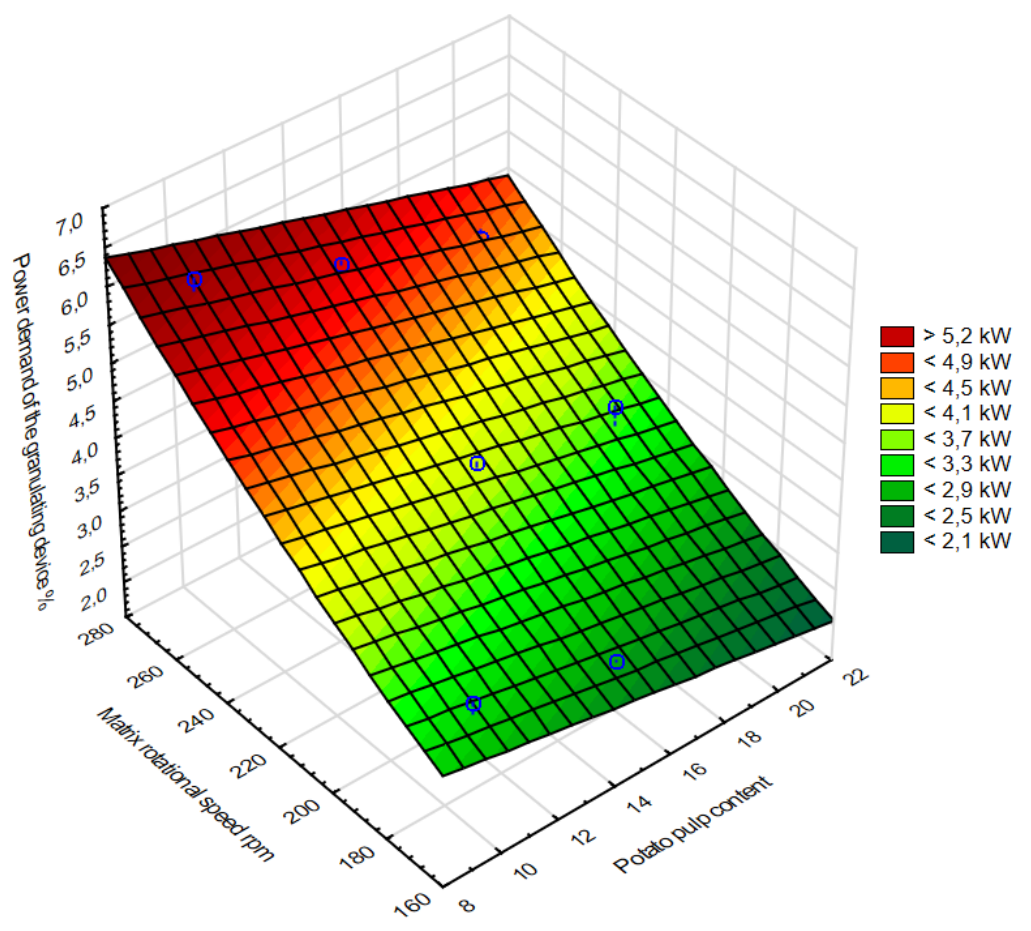

Figure 8. Potato pulp content and rotational speed of the matrix on the granulator demand for power during the production of granulated onion husks.

After analyzing Figure 8, it was found that along with the increase in the proportion of potato pulp from $10 \%$ to $20 \%$ in the mixture with the onion husk, the granulator demand for power decreased. For example, increasing the content of potato pulp from $10 \%$ to $20 \%$ in the mixture (at a rotational speed of $170 \mathrm{rpm}$ ) caused a decrease in the granulator demand for power from 3.25 to $2.23 \mathrm{~kW}$. The reduction in the power demand was caused by a significant increase in moisture in the mix, which resulted from the increased content of the potato pulp. According to Obidziński and colleagues [50], Obidziński [25,27], and Obidziński and Hejft [29], increasing the content of potato pulp in the mixture results in an increase in the binder content (in the form of moisture and starch) during the granulation process. The binder reduces the resistance to the mixture being pressed through the die holes while also reducing the granulator's demand for power. The use of high moisture waste as a binder in granulation processes has also been described by Stahl and Berghel [22], who produced fuel pellets from a mixture of sawdust and post-production turnip waste resulting from the production of turnip oil. They found that as the turnip waste content in the compacted mixture increased, the energy consumption of the pelleting process decreased. Mediavilla et al. [61], by adding corn starch (in an amount of $2.5 \%, 5.0 \%$, 
and $7.0 \%$ ) to the agglomerated mix, obtained a reduction in the power demand of the granulator while at the same time improving the process stability. Brunerová et al. [62], who produced bio-briquettes from waste biomass of tropical fruits (durian, coconut, coffee, cacao, banana, and rambutan), found that the energy demands to produce bio-briquettes from such feedstock materials were lower. The best results (lowest energy consumption in combination with high bio-briquette bulk density) were obtained from the rambutan, durian, and banana samples. Cui et al. [63] produced wood pellets and investigated the usefulness of microalgae as a binder substance to improve the physical and thermal properties of an obtained pellet, decreasing the energy consumption during their production. It was found that under appropriate conditions of pressure (120-200 MPa), temperature $\left(80-160^{\circ} \mathrm{C}\right)$, and moisture content $(6 \%-14 \%)$, microalgae can effectively increase the mechanical durability and bulk density of the pellets and can notably reduce the energy consumption of the pelleting process by $23.5 \%$ to $40.4 \%$.

The tests (Figure 8) allowed the statement that along with the increase of the rotational speed of the granulator matrix, its power demand increases. For example, an increase in the rotational speed of the matrix from 170 to $270 \mathrm{rpm}$ during agglomeration of the mixture with $10 \%$ potato pulp, resulted in an increase in the power demand from 3.25 to $5.99 \mathrm{~kW}$. According to Obidziński [55,64], the speed of the pelleting system most often increases the power demand of the pelletizer; however, it is also highly dependent on the specifics of the agglomerated material.

The multiple regression coefficient for the tested model (equation) was $R^{2}=96.99 \%$, which means a good fit of the model describing the power demand of the granulator during the production of onion husk granules depending on the addition of potato pulp and the rotational speed of the granulator's matrix.

Pellets with the highest obtained kinetic durability (90\% onion husk and $10 \%$ potato pulp) were used in the combustion process due to the automatic fuel dosing system, which requires high-quality pellets. They were also the granules with the highest calorific value among those produced (Figure 4).

\subsection{Emissions}

Table 2 shows the results of the combustion of onion pellets with the addition of $10 \%$ potato pulp. There are no reports in the literature regarding emissions from the combustion of waste onion husks in low-power installations. Therefore, the results obtained were compared to granulates made from cherry stones with the addition of rye bran, which were subjected to combustion in the same installation under similar process conditions [16].

Table 2. Fluegas composition and conditions of combustion of onion husks with $10 \%$ potato pulp compared to pellet made of cherry stones with $20 \%$ rye bran.

\begin{tabular}{ccc}
\hline \multirow{2}{*}{ Parameter } & \multicolumn{2}{c}{ Value } \\
\cline { 2 - 3 } & Onion Husks + Potato Pulp & Cherry Stones + Rye Bran [16] \\
\hline $\mathrm{CO}_{2}[\%]$ & 7.27 & 7.20 \\
$\mathrm{CO}\left[\mathrm{mg} \cdot \mathrm{Nm}^{-3}\right]$ & 703.98 & 432.45 \\
$\mathrm{SO}_{2}\left[\mathrm{mg} \cdot \mathrm{Nm}^{-3}\right]$ & 216.47 & 38.62 \\
$\mathrm{NO}\left[\mathrm{mg} \cdot \mathrm{Nm}^{-3}\right]$ & 307.14 & 264.69 \\
$\mathrm{HCl}\left[\mathrm{mg} \cdot \mathrm{Nm}^{-3}\right]$ & 36.63 & 4.38 \\
$\lambda[-]$ & 14.78 & 10.96 \\
The actual oxygen concentration in the exhaust $[\%]$ & 3.20 & 2.04 \\
Average flue gas temperature in the boiler outlet $\left[{ }^{\circ} \mathrm{C}\right]$ & 120 & 170 \\
\hline
\end{tabular}

From 1 January 2020, only boilers meeting the European Parliament Ecodesign Directive will be able to be installed in the European Union, which extends the requirements of PN EN-303-5:2012 [65] as a limit for seasonal emissions of nitrogen oxides, $\mathrm{NO}_{\mathrm{x}}$. The Ecodesign Directive will regulate the emission of $\mathrm{NO}_{\mathrm{x}}$ to less than $200 \mathrm{mg} \cdot \mathrm{m}^{-3}$ for combustion installations of power lower than $500 \mathrm{~kW}$. Due to the negligible amounts of $\mathrm{NO}_{2}$ in the exhaust gas, only the $\mathrm{NO}$ content is given in Table 2 and compared in the discussion of the $\mathrm{NO}_{\mathrm{x}}$ emission requirements. During combustion, the nitrogen 
contained in the fuel is nearly completely converted into gas nitrogen, $\mathrm{N}_{2}$, and nitrogen oxides, so-called $\mathrm{NO}_{x}$ [66]. Furthermore, the air supply, furnace geometry, combustion temperature, and combustion technology type selected are the main variables having an effect on the $\mathrm{NO}_{x}$ formation $[46,67,68]$.

In Table 2, the actual average quantity of oxygen in the flue gas is given based on the calculated air excess ratio, $\lambda$. The difference in the coefficient, $\lambda$, for pellets from onion husks and cherry stones is clearly visible. In accordance with Pudlik [69], the air excess ratio, $\lambda$, depends on the fuel type and the device in which it is combusted. In terms of waste combustion, it can reach values of 2 to 2.5. However, the higher the $\lambda$, the worse the contact conditions of air with the flammable particles.

Obernberger [70] claims that problems related to $\mathrm{SO}_{\mathrm{x}}$ emissions can be expected when the sulfur content in biomass exceeds $0.2 \%$ by weight, which was reached for both tested wastes: Onion husks and potato pulp. The importance of sulfur is not mainly due to $\mathrm{SO}_{\mathrm{x}}$ emissions but to its role in corrosive processes. According to Spiegel [71] and Obernberger [72], high $\mathrm{SO}_{\mathrm{x}}$ concentrations in exhaust gas contribute to the sulfurization of alkali metal chlorides by reducing the exhaust gas temperature, which leads to the release of chlorine. If these reactions occur in ash particles precipitated on the surface of the heat exchanger tubes, the chlorine released can cause corrosion by forming $\mathrm{FeCl}_{2}$ or $\mathrm{ZnCl}_{2}$ on the heat exchanger surfaces. The presence of sulfur in fuels has a certain positive effect, i.e., a reduction in the risk of chloride corrosion due to the change of the chloride ion in sodium or potassium chlorides to the sulfate ion, which is more temperature stable than chloride [72,73]. Hardy and colleagues [74] report that the risk of chloride corrosion does not occur if the content of chlorine in biomass does not exceed $0.02 \%$. Exceeding this limit was observed only in the case of onion husk. The calculated $\mathrm{S} / \mathrm{Cl}$ ratio for onion husk is about 19.7; therefore, it is much higher than 2.2, and according to literature data [74], the risk of high temperature chloride corrosion is very low. The same authors, Hardy and co-workers [74], claim that counteracting the effects of chloride corrosion can be also based on an assessment of the corrosion threat for a given biomass using the fuel corrosion indicator, where the ratio of sulfur to chlorine in fuel and the share of potassium are taken into account. In this case, further analysis must be provided to investigate the usefulness of onion husk in combustion processes. Onion husk, when used as the main fuel component, contributes to the increase of $\mathrm{SO}_{2}$ emissions; however, as an addition to raw materials rich in chlorine, it may positively reduce the risk of chloride corrosion. Chlorine contained in biomass is mostly released in the form of hydrogen chloride, $\mathrm{HCl}$, during combustion [75], which can later react with other flue gas components and lead to the production of dioxins [76]. The content of $\mathrm{HCl}$ in the exhaust from onion husk pellet combustion is approximately nine times higher than that from the combustion of cherry stones pellets. Rabacal et al. [77] state that the type of granulate significantly affects the boiler efficiency and emission characteristics.

In combustion processes, specific attention is paid to the content of $\mathrm{CO}$ in flue gas as a symptom of the presence of soot, hydrocarbons, dioxins, and furans [78]. The maximum CO content in exhaust from boilers with a heating capacity lower than $0.5 \mathrm{MW}$ is regulated by the Ecodesign Directive and cannot exceed $500 \mathrm{mg} \cdot \mathrm{m}^{-3}$ (when the biomass fuel feeding is automatic), which was also a state of PN EN-303-5: 2012 for five class boilers [65]. The high CO emission value obtained during the combustion of onion husk granules with the addition of potato pulp indicates problems in the oxidation of $\mathrm{CO}$ to $\mathrm{CO}_{2}$ and the low stability of the combustion process [79-82]. Sornek and co-workers [83], in controlling the operation of a stove with the use of a PLC controller (enabling the control of the amount of air dispensed to the combustion chamber) and an exhaust gas analyzer (taking into account mainly CO emissions), state that it is possible to achieve the operating parameters required by the BImSchV 2 and Ecodesign standards.

\section{Conclusions}

The densification process (pressure agglomeration, granulation), its energy consumption, efficiency, and the quality of the obtained product are related to many material, apparatus, and process factors. The deciding objective of the creation of fuel pellets from agri-food waste is the need to develop 
new management systems of production residues, which will allow a reduction of the costs of their utilization due to their use in energy production systems.

The pressure agglomeration process of wastes from the agri-food industry requires the selection of appropriate material, process, and equipment conditions for each type of waste. The highest quality of pellets from onion skins and potato pulp was obtained with the $10 \%$ potato pulp addition and the rotational speed of the granulator matrix as $\mathrm{n}_{\mathrm{m}}=170 \mathrm{rpm}$.

The use of potato pulp as a binder reduces the calorific value and heat of combustion of the granulate; however, due to the content of starch and its binding properties, at the granulation temperature, it facilitates the process, acting as a lubricant and reduces the granulator's demand for power.

The conducted tests of the combustion of the produced granules allowed verification of their usefulness as solid fuels for use in low-power boilers with a retort grate. Due to the high content of $\mathrm{CO}$ and $\mathrm{NO}$, which do not meet the requirements of the Ecodesign Directive and high $\mathrm{SO}_{2}$ emission, further research must be carried out in the case of thermal utilization of onion husks for energy purposes. The authors suggest that due to the high sulfur content, it is possible to add onion husks to materials with high chlorine contents, which could result in a lower risk of chloride corrosion. Optimized boiler structures for biomass combustion, equipped with systems for mixing secondary air with combustion products, can lead to a reduction in $\mathrm{NO}_{\mathrm{x}}$ and $\mathrm{CO}$ emissions and allow the combustion of fuels formed from agri-food waste, whose thermal processing is difficult in installations with a less complicated structure.

The research carried out on the pressure agglomeration of agri-food waste and its thermal utilization allows the statement that there is a need to carry out comprehensive analyses on the granulation of plant waste materials available on the Polish market, which will allow the selection of the best composition of agglomerates in terms of their subsequent use as fuel for combustion, with the possibly limited emission of compounds harmful to the environment and human health. Moreover, considerations on the use of agri-food waste in energy systems require a deeper analysis of their usefulness, e.g., analysis of the composition of the soot formed, analysis of the dust content in exhaust gases, and examination of the content of long-chain compounds in exhaust gases. This work is an introduction to these considerations and requires further analysis.

Author Contributions: For research articles with several authors, a short paragraph specifying their individual contributions must be provided. The following statements should be used "conceptualization, M.D. and S.O.; methodology, S.O.; software, M.K.-S.; validation, M.D., M.K.-S. and S.O.; formal analysis, M.D.; investigation, M.D.; resources, K.J., M.D., S.O., P.S.; data curation, M.D., M.K.-S., K.J. and S.O.; writing—original draft preparation, M.D.; writing-review and editing, M.D., P.S. and S.O.; visualization, M.K.-S.and S.O.; supervision, S.O.; project administration, S.O.; funding acquisition, S.O."

Funding: This research was funded by the Polish Ministry of Science and Higher Education as part of the statutory work number S/WBiIŚ/2/15.

Conflicts of Interest: The authors declare no conflict of interest.

\section{References}

1. Dołżyńska, M.; Obidziński, S.; Kowczyk-Sadowy, M.; Krasowska, M.; Karczewski, K.; Jóźwiak, D.; Buczyński, R. Pressure Agglomeration Process of Bakery Industry Waste. Proceedings 2019, 16, 37. [CrossRef]

2. European Parliament and of the Council of 19 November 2008 on waste and repealing certain Directives, OJ L312/3-30 of 22.11.2008. Available online: https://eur-lex.europa.eu/legal-content/EN/TXT/?uri=celex\% 3A32008L0098 (accessed on 1 October 2019).

3. Czekała, W.; Lewicki, A.; Pochwatka, P.; Czekała, A.; Wojcieszak, D.; Jozwiakowski, K.; Waliszewska, H. Digestate management in polish farms as an element of the nutrient cycle. J. Clean. Prod. 2020, 242, 118454. [CrossRef]

4. Czekała, W. Agricultural Biogas Plants as a Chance for the Development of the Agri-Food Sector. J. Ecol. Eng. 2018, 19, 179-183. [CrossRef] 
5. Cengiz, N.Ü.; Yıldız, G.; Sert, M.; Gokkaya, D.S.; Saglam, M.; Yüksel, M.; Ballice, L. Hydrothermal gasification of a biodiesel by-product crude glycerol in the presence of phosphate based catalysts. Int. J. Hydrogen Energy 2015, 40, 14806-14815. [CrossRef]

6. Galanakis, C.M. Recovery of high added-value components from food waste: Conventional, emerging technologies and commercialized applications. Trends Food Sci. Technol. 2012, 26, 68-87. [CrossRef]

7. Laufenberg, G.; Kunz, B.; Nystroem, M. Transformation of vegetable waste into value added products: (A) the upgrading concept; (B) practical implementations. Bioresour. Technol. 2003, 87, 167-198. [CrossRef]

8. Lin, C.S.K.; Pfaltzgraff, L.A.; Herro-Davilas, L.; Mubofu, E.B.; Abderrahim, S.; Clark, J.H.; Koutinas, A.A.; Kopsahelis, N.; Stamatelatou, K.; Dickson, F.; et al. Food waste as a valuable resource for the production of chemicals, materials and fuels. Current situation and global perspective. Energy Environ. Sci. 2013, 6, 426-464. [CrossRef]

9. Polish Journal of Laws 2001 No. 62 item 628. Act of 27 April 2001 on waste. Available online: https://www.global-regulation.com/translation/poland/10093814/the-act-of-27-april-2001\%252c-theenvironmental-protection-law.html (accessed on 2 October 2019).

10. Benitéz, V.; Molla, E.; Martin-Cabrejas, M.A.; Aguilera, Y.; Lopez-Andreu, F.J.; Cools, K.; Terry, L.A.; Esteban, R.M. Characterization of industrial onion wastes (Allium cepa L): Dietary fiber and bioactive compounds. Plant Foods Hum. Nutr. 2011, 66, 48-57. [CrossRef]

11. Waldron, K.W. Useful ingredients from onion waste. Food Sci. Technol. 2001, 15, 38-41.

12. Ly, T.; Hazama, C.; Shimoyamada, M.; Ando, H.; Kato, K.; Yamauchi, R. Antioxidative compounds from the outer scales of onion. J. Agric. Food Chem. 2005, 53, 8183-8189. [CrossRef]

13. Roldan, E.; Sanchez-Moreno, C.; Ancos, B.; Cano, M. Characterization of onion (Allium cepa L.) products as food ingredients with antioxidant and antibrowning properties. Food Chem. 2008, 108, 907-916. [CrossRef] [PubMed]

14. Albishi, T.; John, J.; Al-Khalifa, A.; Shahidi, F. Antioxidative phenolic constituents of skin of onion varieties and their activities. J. Funct. Foods 2013, 5, 1191-1203. [CrossRef]

15. Obidziński, S.; Hejft, R.; Dołżyńska, M. Badanie procesu granulowania odpadów zbożowych/Research on granulation of cereal waste. Przemyst Chem. 2017, 96, 2360-2363.

16. Dołżyńska, M.; Obidziński, S.; Kowczyk-Sadowy, M.; Krasowska, M. Densification and Combustion of Cherry Stones. Energies 2019, 12, 3042. [CrossRef]

17. Ohman, M.; Boman, C.; Hedman, H.; Eklund, R. Residential combustion performance of pelletized hydrolysis residue from lignocellulosic ethanol production. Energy Fuels 2006, 20, 298-304. [CrossRef]

18. Miranda, T.; Arranz, J.I.; Montero, I.; Román, S.; Rojas, C.V.; Nogales, S. Characterization and combustion of olive pomace and forest residue pellets. Fuel Process. Technol. 2012, 103, 91-96. [CrossRef]

19. Chou, C.S.; Lin, S.H.; Lu, W.C. Preparation and characterization of solid biomass fuel made from rice straw and rice bran. Fuel Process. Technol. 2009, 90, 980-987. [CrossRef]

20. Chou, C.S.; Lin, S.H.; Peng, C.C.; Lu, W.C. The optimum conditions for preparing solid fuel briquette of rice straw by a piston-mold process using the Taguchi method. Fuel Process. Technol. 2009, 90, 1041-1046. [CrossRef]

21. Celma, A.R.; Cuadros, F.; López-Rodríguez, F. Characterization of pellets from industrial tomato residues. Food Bioprod. Process. 2012, 90, 700-706. [CrossRef]

22. Stahl, M.; Berghel, J. Energy efficient pilot-scale production of wood fuel pellets made from a raw material mix including sawdust and rapeseed cake. Biomass Bioenergy 2011, 35, 4849-4854. [CrossRef]

23. Sotannde, O.A.; Oluyege, A.O.; Abah, G.B. Physical and combustion properties of charcoal briquettes from neem wood residues. Int. Agrophisics 2010, 24, 189-194.

24. Chachułowa, J. Pasze/Feed; Wydawnictwo Fundacja Rozwój SGGW: Warszawa, Poland, 1997.

25. Obidziński, S. Analysis of usability of potato pulp as solid fuel. Fuel Process. Technol. 2012, 94, 67-74. [CrossRef]

26. Obidziński, S. Pelletization of biomass waste with potato pulp content. Int. Agrophys. 2014, $28,85-91$. [CrossRef]

27. Obidziński, S. Utilization of post-production waste of potato pulp and buckwheat hulls in the form of pellets. Pol. J. Environ. Stud. 2014, 23, 1391-1395.

28. Obidziński, S.; Joka, M.; Bieńczak, A.; Jadwisieńczak, K. Tests of the process of post-production onion waste pelleting. J. Res. Appl. Agric. Eng. 2017, 62, 89-92. 
29. Obidziński, S.; Hejft, R. The influence of potato pulp addition to the oat bran on the energy consumption of the pelletisation process and pellets quality. J. Res. Appl. Agric. Eng. 2013, 58, 133-138.

30. PN-R-64798: 2009. Feed - Determination of fragmentation; Polish Committee for Standardization: Warsaw, Poland, 2009.

31. PN-EN 14774-1: 2010. Solid biofuels - Determination of moisture content - Drying method - Part 1: Total moisture Reference method; Polish Committee for Standardization: Warsaw, Poland, 2010.

32. PN-EN ISO 17828:2016. Solid biofuels - Determination of bulk density; Polish Committee for Standardization: Warsaw, Poland, 2016.

33. PN-EN ISO 16948:2016. Solid biofuels - Determination of total carbon, hydrogen and nitrogen content; Polish Committee for Standardization: Warsaw, Poland, 2016.

34. PN-EN ISO 16994:2016. Solid biofuels - Determination of total sulfur and chlorine content; Polish Committee for Standardization: Warsaw, Poland, 2016.

35. PN-EN ISO 18123:2017. Solid biofuels - Determination of volatile matter; Polish Committee for Standardization: Warsaw, Poland, 2017.

36. PN-EN ISO 18134:2017. Solid biofuels - Determination of moisture content - Drying method - Part 3: Moisture in the sample for general analysis; Polish Committee for Standardization: Warsaw, Poland, 2017.

37. PN-EN ISO 18122:2017. Solid biofuels - Determination of ash content; Polish Committee for Standardization: Warsaw, Poland, 2017.

38. PN-ISO 1928:2002. Solid fuels - Determination of heat of combustion by calorimetric bomb method and calorific value calculation; Polish Committee for Standardization: Warsaw, Poland, 2002.

39. PN-R-64834:1998. Feed - Test for the kinetic strength of granules; Polish Committee for Standardization: Warsaw, Poland, 1998.

40. Dołżyńska, M.; Obidziński, S.; Simiński, P. Ocena granulatów z odpadów konopi siewnej jako biopaliwa/Evaluation of granulates from hemp waste as a biofuel. Przemyst Chem. 2018, 97, 686-688.

41. Frączek, J.; Kurpaska, S.; Łapczyńska-Kordon, B. Thermal Conversion of Biomass; Polskie Towarzystwo Inżynierii Rolniczej: Kraków, Poland, 2011.

42. Szatyłowicz, E.; Skoczko, I. Evaluation of the PAH Content in Soot from Solid Fuels Combustion in Low Power Boilers. Energies 2019, 12, 4254. [CrossRef]

43. Demirbaş, A. Combustion characteristics of different biomass fuels. Prog. Energy Combust. Sci. 2004, 30, 219-230. [CrossRef]

44. Dołżyńska, M.; Obidziński, S. Wpływ dodatku zużytego oleju spożywczego na efekty spalania osadów ściekowych/Impact of used cooking oil addition on the effects of burning sewage sludge. Przemyst Chem. 2017, 96, 1848-1851.

45. Stępień, J.C.; Salij, A.; Psuj, K. Analiza techniczna i elementarna wybranych rodzajów biomasy oraz węgla kamiennego/Technical and elemental analysis of selected types of biomass and hard coal. Rynek Energii 2018, 3, 65-69.

46. Lewandowski, W.M.; Ryms, M. Biopaliwa: Proekologiczne Odnawialne Źródła Energii/Biofuels: Pro-Ecological Renewable Energy Sources; Wydawnictwo WNT: Warszawa, Poland, 2013.

47. Obernberger, I.; Brunner, T.; Barnthaler, G. Chemical properties of solid biofuels—Significance and impact. Biomass Bioenergy 2006, 30, 973-982. [CrossRef]

48. Saidur, R.; Abdelaziz, E.A.; Demirbaş, A.; Hossaina, M.S.; Mekhilef, S. A review on biomass as a fuel for boilers. Renew. Sustain. Energy Rev. 2011, 15, 2262-2289. [CrossRef]

49. Kriżan, M.; Kristof, K.; Angelović, M.; Jobbagy, J.; Urbanovićova, O. Energy potential of densified biomass from maize straw in form of pellets and briquettes. Agron. Res. 2018, 16, 474-482.

50. Zajac, G.; Szyszlak-Bargłowicz, J. Wpływdodatkuotrabżytnichnawłasnościenergetycznepeletów z biomasyślazowcapensylwańskiego/The influence of rye bran additive on energy properties of pellets from syllab of Columbian mallow. Autobusy Tech. Eksploat. Syst. Transp. 2011, 10, 459-464.

51. Obidzinski, S.; Piekut, J.; Dec, D. The influence of potato pulp content on the properties of pellets from buckwheat hulls. Renew. Energy 2016, 87, 289-297. [CrossRef]

52. Zwiślak, K.; Sobczak, P.; Panasiewicz, M.; Mazur, J.; Nadulski, R.; Starek, A. Wpływ wielkości frakcji otrąb pszennych na jakość granulatu. Inżynieria Przetwórstwa Spożywczego 2014, 3, 25-28. 
53. Castellano, J.M.; Gómez, M.; Fernández, M.; Esteban, L.S.; Carrasco, J.E. Study on the effects of raw materials composition and pelletization conditions on the quality and properties of pellets obtained from different woody and non woody biomasses. Fuel 2015, 139, 629-636. [CrossRef]

54. Kaliyan, N.; Morey, R.V. Natural binders and solid bridge type binding mechanisms in briquettes and pellets made from corn stover and switchgrass. Bioresour. Technol. 2010, 101, 1082-1090. [CrossRef]

55. Kaliyan, N.; Morey, R.V. Factors affecting strength and durability of densified biomass products. Biomass Bioenergy 2009, 33, 337-359. [CrossRef]

56. Alakangas, E.; Paju, P. Wood Pellets in Finland_Technology, Economy and Market; OPET Report 5; VTT Processes: Jyvaskyla, Finland, 2002.

57. Obidziński, S. Doctoral dissertation. In Pelleting of Plant Materials in an Annular Granulator Working System; Bialystok University of Technology: Białystok, Poland, 2005.

58. Hejft, R. Ciśnieniowa Aglomeracja Materiałów Roślinnych/Pressure Agglomeration of Plant Materials; Biblioteka Problemów Eksploatacji, Radom: Białystok, Poland, 2002.

59. Jiang, L.; Liang, J.; Yuan, X.; Li, H.; Li, C.; Xiao, Z. Co-pelletization of sewage sludge and biomass: The density and hardness of pellet. Bioresour. Technol. 2014, 166, 435-443. [CrossRef] [PubMed]

60. Li, H.; Jiang, L.B.; Li, C.Z.; Liang, J.; Yuan, X.Z.; Xiao, Z.H. Co-pelletization of sewage sludge and biomass: The energy input and properties of pellets. Fuel Process. Technol. 2015, 132, 55-61. [CrossRef]

61. Mani, S.; Tabil, L.G.; Sokhansanj, S. Effects of compressive force, particle size and moisture content on mechanical properties of biomass pellets from grasses. Biomass Bioenergy 2006, 30, 648-654. [CrossRef]

62. Brunerová, A.; Roubík, H.; Brožek, M.; Herák, D.; Šleger, V.M. Potential of Tropical Fruit Waste Biomass for Production of Bio-Briquette Fuel: Using Indonesia as an Example. Energies 2017, 10, 2119. [CrossRef]

63. Cui, X.; Yang, J.; Shi, X.; Lei, W.; Huang, T.; Bai, C. Experimental Investigation on the Energy Consumption, Physical, and Thermal Properties of a Novel Pellet Fuel Made from Wood Residues with Microalgae as a Binder. Energies 2019, 12, 3425. [CrossRef]

64. Shaw, M.D.; Tabil, L.G. Compression and relaxation characteristics of selected biomass grinds. In Proceedings of the ASAE Annual International Meeting, Minneapolis, MN, USA, 17-20 June 2007; ASAE Paper No. 076183; ASAE: St. Joseph, MI, USA, 2007.

65. Mediavilla, I.; Esteban, L.S.; Fernández, M.J. Optimisation of pelletisation conditions for poplar energy crop. Fuel Process. Technol. 2012, 104, 7-15. [CrossRef]

66. Obidziński, S.; Joka, M.; Fijoł, O. Two-stage agglomeration of fine-grained herbal waste of nettle. Int. Agrophisics 2017, 31, 515-523. [CrossRef]

67. PN EN-303-5: 2012. Boilers - Part 5: Boilers for solid fuels with manual and automatic fuel feed with a nominal power of up to $500 \mathrm{~kW}$ - Terminology, requirements, testing and marking; Polish Committee for Standardization: Warsaw, Poland, 2012.

68. Nussbaumer, T. Combustion and co-combustion of biomass. In Proceedings of the 12th European Biomass Conference, Amsterdam, The Netherlands, 17-21 June 2002.

69. Glarborg, P.; Miller, J.A.; Ruscic, B.; Klippenstein, S.J. Modeling nitrogen chemistry in combustion. Prog. Energy Combust. Sci. 2018, 67, 31-68. [CrossRef]

70. Mladenović, M.; Paprika, M.; Marinković, A. Denitrification techniques for biomass combustion. Renew. Sustain. Energy Rev. 2018, 82, 3350-3364. [CrossRef]

71. Pudlik, W. Termiczna Przeróbka Odpadów. Podstawy teoretyczne/Thermal Waste Treatment. Theoretical Basics; WydawnictwoPolitechniki: Gdańskiej, Poland, 2014.

72. Obernberger, I. Physical characteristics and chemical composition of solid biomass fuels. Thermochemical Biomass Conversion; Script for the Lecture; Eindhofen University of Technology, Department for Mechanical Engineering, Section Process Technology: Eindhofen, The Netherlands, 2003.

73. Spiegel, M. Corrosion in molten salts. Mater. Sci. Mater. Eng. 2010, 1, 316-330.

74. Obernberger, I. Nutzung fester Biomasse in VerbrennungsanlagenunterbesondererBerücksichtigung des Verhaltensaschebildender Elemente; Schriftenreihe Thermische Biomassenutzung, Band 1; Osterreichdbv-Verlag der Technischen Universitat Graz: Graz, Austria, 1997.

75. Król, D.; Borsukiewicz-Gozdur, A. Energy from sawmill and agricultural waste biomass. ArchiwumGospodarkiOdpadamiiOchronyŚrodowiska 2014, 16, 87-94.

76. Hardy, T.; Kordylewski, W.; Mościcki, K. Zagrożenie korozją chlorkową w wyniku spalania i współspalania biomasy w kotłach. ArchiwumSpalania 2009, 9, 181-195. 
77. Ren, X.; Sun, R.; Chi, H.-H.; Meng, X.; Li, Y.; Levendis, Y.A. Hydrogen chloride emissions from combustion of raw and torrefiedbiomass. Fuel 2017, 200, 37-46. [CrossRef]

78. Williams, A.; Jones, J.M.; Ma, L.; Pourkashanian, M. Pollutants from the combustion of solid biomass fuels. Prog. Energy Combust. Sci. 2012, 38, 113-137. [CrossRef]

79. Rabacal, M.; Fernandes, U.; Costa, M. Combustion and emission characteristics of a domestic boiler fired with pellets of pine, industrial wood wastes and peach Stones. Renew. Energy 2013, 51, 220-226. [CrossRef]

80. Wandrasz, J.W.; Wandrasz, A.J. Paliwa Formowane Biopaliwai Paliwa z Odpadów w Procesach Termicznych/Fuels Formed by Biofuels and Fuels from Waste in Thermal Processes; Wyd. Seidel-Przywecki: Warszawa, Poland, 2006.

81. Szyszlak-Bargłowicz, J.; Zając, G.; Słowik, T. Badanie emisji wybranych zanieczyszczeń gazowych podczas spalania peletów z agro biomasy w kotle małej mocy. RocznikOchronaŚrodowiska 2017, 19, 715-730.

82. Zając, G.; Szyszlak-Bargłowicz, J.; Gołębiowski, W.; Szczepanik, M. Chemical Characteristics of Biomass Ashes. Energies 2018, 11, 2885. [CrossRef]

83. Sornek, K.; Filipowicz, M.; Kurcz, L.; Szubel, M.; Rosół, M.; Rzepka, K.; Ręka, J. Sterowaniepracapiecokominka a emisjatlenkuwegla do atmosfery/Controlling the operation of the fireplace stove and the emission of carbon monoxide into the atmosphere. InżynieriaiOchronaŚrodowiska 2015, 18, 497-512.

(C) 2019 by the authors. Licensee MDPI, Basel, Switzerland. This article is an open access article distributed under the terms and conditions of the Creative Commons Attribution (CC BY) license (http://creativecommons.org/licenses/by/4.0/). 